\title{
The Innovation of Regional Typical Food Products Enye Bogarasa Chips in an Effort to Improve the Community's Economy in the Village of Mekarmukti Waluran Sukabumi Regency
}

\author{
Dicky Jhoansyah ${ }^{1}$, Indra Griha Tofik Isa ${ }^{2}$, Iwan Rizal Setiawan ${ }^{3}$ \\ \{dicky.jhoansyah@gmail.com ${ }^{1}$, igtiku@gmail.com² ${ }^{2}$ myfrank@gmail.com ${ }^{3}$ \} \\ Universitas Muhammadiyah Sukabumi, Indonesia ${ }^{1,2,3}$
}

\begin{abstract}
Purpose - The purpose of community service is an increase in sales and the product enye chips became known as a typical local product Mekarmukti Waluran village. Conceptual framework/Action Method of Activities - the stages of activities include: Initial briefing of farmer group "BOGARASA", product Innovation, assistance and registration for home industry licensing (P-IRT), create an account online media and online shop promotion and online promotion training. Findings - The problem faced is that in general the public has not realized that the typical enye chips Mekarmukti Waluran can be appointed as a potential regional product that can attract the interest of tourists who will travel to the Ciletuh geopark. Based on the facts in the field, there are some specific things why this happened including fewer media promotion, unattractive product packaging, limited taste variants, there is no product legalization and local government does not know about the potential of chips and can have an impact on declining income in communities in the village area of Mekarmukti Waluran.
\end{abstract}

Keywords: Product Innovation, Regional Typical Food, Improve Community Income.

\section{Introduction}

Sukabumi regency is the second-largest regency in java after Banyuwangi regency with an area of $4,161 \mathrm{~km} 2$ or $11.21 \%$ of the area of west java. Sukabumi regency has diverse natural potential with a pluralistic society and administratively has 47 districts. Badan Pusat Statistik Kabupaten Sukabumi from the economic side, the highest scope of work of the people of Sukabumi regency is in the fields of agriculture, forestry and plantation with a percentage weighting of $23.35 \%$ and the rest are divided into the service sector, construction, wholesale trade, and so on [1]. This indicates that some segments of the Sukabumi community are highly dependent on the agriculture, forestry and plantation sectors, one of which is Waluran district with $78 \%$ of the population being farmers, with the main commodities being rice and cassava. administratively Waluran sub-district is in charge of 6 villages namely: Caringinnunggal village, Mangunjaya village, Mekarmukti village, Sukamukti village, Waluran village also Waluran mandiri village. Particularly Waluran village which is a producer of cassava village, making the village has cassava farmer groups that produce refined products such as enye chips are made from raw cassava. The following figure 1 shows a map of Mekarmukti Waluran district and the surrounding villages. 
Especially in the Sunda area, enye chips is one of the favorite snacks in all segments of the community, because besides being cheap it also tastes delicious and tasty. Another thing that is owned by enye chips Mekarmukti Waluran has a savory taste that is different from enye chips made in other regions because it comes from cassava which has the best quality with a harvest period of 8-20 months [2]. waluran village itself is located at an altitude of $380-880$ meters above sea level [3], and this is ideal for growing cassava plants. So that the cassava produced in Mekarmukti Waluran village has the right blend of sweetness, which causes the typical enye chips Mekarmukti Waluran has different savory characteristics. The typical selling price for enye chips Mekarmukti Waluran ranges from Rp 12,000 - Rp 15,000 per kilogram. Manufacture of enye chips do not use chemical preservatives, but with the way drained even been able to extend the life of expiry. In addition, innovations in cassava peel waste can be utilized and can be reused for feed. This training will be introduced on how to manage cassava peel so that it can be reused for cheap and easy feed for livestock. Long immersion can reduce cyanide content to safe limits for goat/sheep consumption [2][3].

The problem that occurs is the traditional form of enye chips and the lack of promotion of products produced by farmers in the Wekarmukti waluran sub-district and less attention from the local government, in this case the village government as a link to the potential of tourism products that can be sold to the tourists who are visiting the Ciletuh geopark attraction area. But also based on facts on the ground, there are specific things why this happened:

a) Less media promotion

The main obstacle why Mekarmukti Waluran chips are not so well known, especially around the regencies and cities of Sukabumi is the lack of media promotion for example through online and newspaper, which is done today is still traditional, which relies on word of mouth promotion or person-to-person fellow tourists who buying chips enye, certainly will not provide maximum sales results. this was conveyed in the results of discussions with the head of the farmer group "BOGARASA", namely Mrs. Enay, that in the last 2 years there has been a decline in sales of enye chips and the rest of the unsold products will be stored up to mold which has no sale value so that enye chips will be wasted.

b) Unattractive product packaging and limited taste variants

Packaging products that are still traditional and not many variations of taste make these chips not easy to remember and known by tourists. for example, every sale of enye Mekarmukti Waluran chips is wrapped in an ordinary plastic bag and wrapped in a black bag and the flavor variants are still limited to the original flavor (salty with spices). The taste is still limited because the producers of enye chips have not yet dared to develop new flavor variants for fear of not selling well in the market and tourists. From an aesthetic point of view, it can be concluded that this is what makes enye chips less well known by people outside the village of Mekarmukti Waluran. It is undeniable that good packaging can be a parameter for buyers to decide to make a purchase on a particular product. in the sale of enye chips on a large scale, they still use wrapping bags in the form of used rice sacks. Although the chips produced have the best quality with a sense of character that represents the village of Mekarmukti Waluran but with improper packaging will produce an unfavorable image as well.

c) There is no product legalization

Sometimes the buyer will ask that certain products are safe for consumption or not. For example, product legalization is required by the food and drug supervisory agency. One of the permits that must be owned by a home industry like this is a P-IRT permit. enye chips Mekarmukti Waluran itself does not yet have a P-IRT permit, this has an 
impact on the difficulty of enye chips Waluran expansion is enjoyed by consumers who are outside Sukabumi regency and around Cianjur and Bogor. This factor also causes the enye chips Waluran less competitive with other producers of enye chips. Even for the city of Sukabumi and surrounding areas the tendency to choose a type of enye chips produced in areas outside west java, such as the Solo area as a producer of enye chips which is packaged in attractive packaging and includes a P-IRT permit number.

d) Local government does not know about the potential of enye chips

One of the successes of small and micro industries is the role of the community and local government, for example in this context is the village government of Mekarmukti Waluran district. What has happened is that the village government of Waluran has not yet realized that the typical Waluran enye chips can be made into a regional specialty for tourists who will visit the Ciletuh geopark. Given the village, the government focused on managing rubber and tea plantations. With the appointment of enye chips as one of the main commodities in the village of Mekarmukti, the sub-district of Waluran, this can improve the economy of the community because the majority of workers are women of productive age who are highly dependent on this business. meaning that if sales and business income decline, it will have an impact on the income of its workers.

\section{Action Method of Activities}

In this community dedication activity, a clear stage is needed in the form of the research method of activity and Innovation is the lifeblood of successful companies, so that the purpose of community dedication is achieved [4][5]. The overall picture of the research method is in Figure 1 below:

\begin{tabular}{|c|c|c|c|c|}
\hline $\begin{array}{l}\text { Initial } \\
\text { briefing on } \\
\text { "Bogarasa" } \\
\text { farmer groups }\end{array}$ & & $\begin{array}{l}\text { Assistance and } \\
\text { registration for } \\
\text { home industry } \\
\text { licensing (P- } \\
\text { IRT) }\end{array}$ & & $\begin{array}{l}\text { Online } \\
\text { promotion } \\
\text { training }\end{array}$ \\
\hline & $\begin{array}{l}\text { Product Innovation: } \\
\text { 1. Branding } \\
\text { 2. Labelling } \\
\text { 3. Packaging } \\
\text { 4. Variants of Taste, } \\
\text { Shape, and Size }\end{array}$ & & $\begin{array}{l}\text { Create an } \\
\text { account } \\
\text { online media } \\
\text { and online } \\
\text { shop } \\
\text { promotion }\end{array}$ & \\
\hline
\end{tabular}

Fig. 1. Stages of Activity

The following explanation from the chart in Figure 1 above:

\subsection{Initial briefing of farmer group "BOGARASA"}

As for socialization of the community partnership program that will be implemented, it is needed support from various levels of society in the Waluran village. This activity will invite 
several representatives from the community that the "BOGARASA" farmer group community dedication will be held and an initial workshop will be held to expose the work program to be implemented. some community representatives who will be invited are: a) "BOGARASA" farmer group; b) A representative of the village head; c) Youth organization representative; d) Waluran village government representative

\subsection{Product Innovation}

4 things will be done in this activity, namely determining branding, labeling, packaging and product development. As for the implementation, it will involve students as a technical part and input creative ideas in collaboration with the standards in the "BOGARASA" Farmer Group. The process of making this sampling product will be carried out repeatedly, to maximize product sampling formulation in terms of packaging, form Enye, and flavor variants:

a) Branding

Branding in a product is needed to show the identity, characteristics, and concept of the product. In this case, where the typical enye chips Waluran does not yet have strong branding. With the strong branding of this enye chips product, it produces more selling value for consumers. The branding activities are: (1) Determine brand products that have marketable/market value; (2) Determine the tagline that represents the typical enye chips Waluran as a souvenir that must be tasted when tourists travel to the Ciletuh Geopark; (3) Determine the product logo which has philosophical value as an interpretation of the typical Waluran enye chips.

b) Labeling

After the concept of branding already exists, next is labeling. Labeling here is to pour the branding into the packaging design. In this stage, creative ideas are needed to express these ideas. From the start of selection of letters, color selection, shape and size of the packaging.

c) Packaging

The packaging is made using an ergonomic concept that has a good aesthetic side.

d) Product development

To develop the product so that it enters into all segments, apart from the Original flavor, a supplementary spice will be added as a flavor variant, by not changing the composition of the ingredient for making enye chips. The addition of flavor variants consists of 4 flavors namely: (1) cheese flavor; (2) balado flavor; (3) taste of barbecue; (4) onion chicken taste.

\subsection{Assistance and registration for home industry licensing (P-IRT)}

The material provided in this activity are:

a) Describe the general description of P-IRT.

b) The importance of licensing in marketing a product.

c) Procedures and requirements for registering P-IRT.

d) The P-IRT registration assistance process until the issuance of a PIRT permit issued by the health office.

e) Food laboratory tests to determine the composition of nutrients or nutrients contained in enye chips. When the laboratory test is known and recommended by the department of health it will be included in the package enye chips. 
In assisting until the issuance of the P-IRT permit, the partnership program team will conduct monitoring and coordination both to the "BOGARASA" farmer group, coordinated by the chair of the farmer group, namely Mrs. Enay, as well as the party issuing the P-IRT permit namely the Sukabumi district health office. Monitoring and coordination will take place within 1-2 months, until the issuance of a P-IRT permit.

\subsection{Create an account online media and online shop promotion}

The "BOGARASA" Farmer Group has conventionally been marketing, but only "waiting for the ball", without "picking up the ball". In this activity, the community dedication Team will direct the concept of product marketing with social media Instagram and youtube by involving the "BOGARASA" farmer group.

\subsection{Online promotion training}

This activity aims to educate the public especially marketers of Waluran distinctive enye chips. In this activity will involve young people in the village of Waluran who are members of the youth organization and of course the farmer group "BOGARASA".

\section{Results and Discussion}

\subsection{Initial Workshop}

This activity is the initial stage as part of the introduction of work programs to partners. In this activity, it is explained what work programs will be carried out which include:

a) Brainstorming and making product branding concepts.

b) Brainstorming product development which includes dimensions of enye chips, flavor variants, product innovation.

c) Product logo creation.

d) Socialization of home industry licensing (P-IRT) needs.

e) Assistance for home industry licensing registration (P-IRT).

f) Account creation and online marketing assistance through social media and online shop: Instagram, YouTube etc.

g) Collaboration with the tourism office of Sukabumi regency and those who will assist in the marketing of products, such as the display tourism community and the Ciletuh geopark tourism community.

The workshop participants included representatives from the community consisting of the village party represented by the village head and his staff, the district party represented by the Camat secretary, the farmer group "BOGARASA" and the youth who were members of the youth organization. the workshop activities are carried out on:
Day/Date
: Friday/March 29, 2019
At : 09:00-15:00
Place of Activity
: Waluran Mekarmukti village hall 
as a result of the workshop activities, the community will support the activity of enhancing the industry of enye chips as a local potential that can be raised in supporting display tourism, especially in the Ciletuh geopark area.

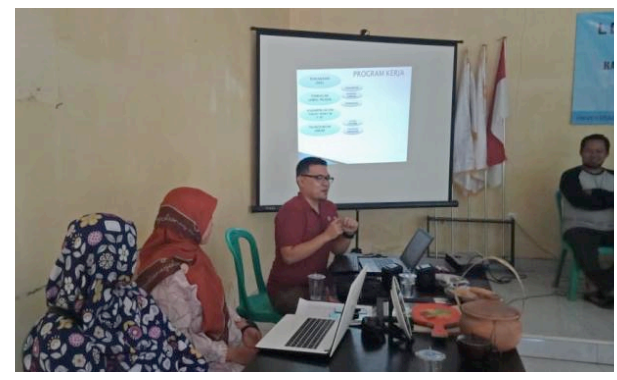

(a) Expose the work program activities with partners

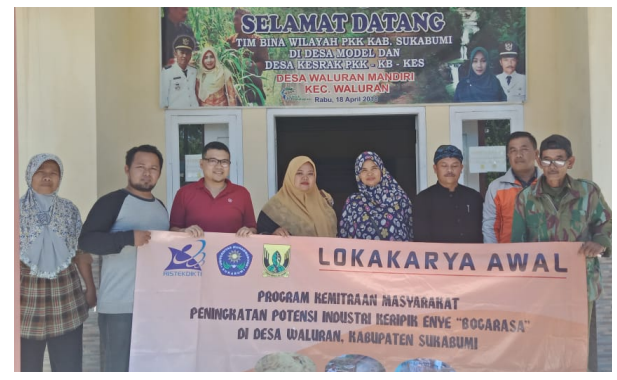

(b) Together with the farmer groups "Bogarasa", community representatives and the Waluran Mekarmukti village apparatus

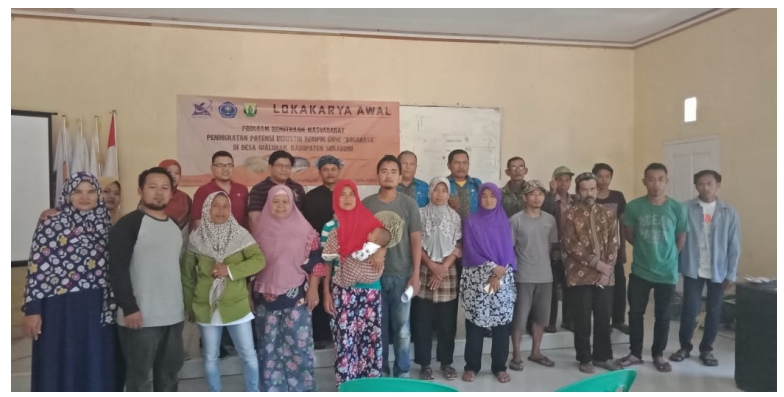

(c) Closing of workshop activities

\subsection{Brainstorming brand products and packaging}

In this activity carried out with the farmer group " BOGARASA" regarding input and suggestions for the proposed product brand. Some of the proposed brands include:

a) Enye emak opik is based on a phenomenal figure with a concept "Everything that was big was small"

b) Enye blue pink which is quite a bit with k-pop

c) Enye boa uenak, with jargon rather than boa edan better boa uenak

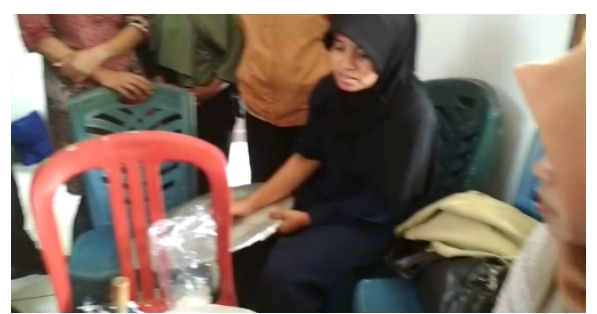

Fig. 2. Brainstorming activities with the villagers

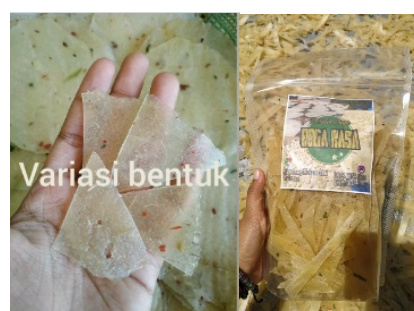

Fig. 3. Variation of Packaging 


\subsection{Brainstorming product prototyping}

In this activity planning for a product, innovation is carried out. The activity was carried out with an experiment in making enye chips which changed in terms of thickness, size, flavoring experiments. For the dimension enye chips, originally $5 \mathrm{~cm}$ in diameter will be reduced to $2.5 \mathrm{~cm}$. It is intended that enye chips occupy the entire packaging space, and minimize unoccupied cavities. As seen in Figure 3 below:

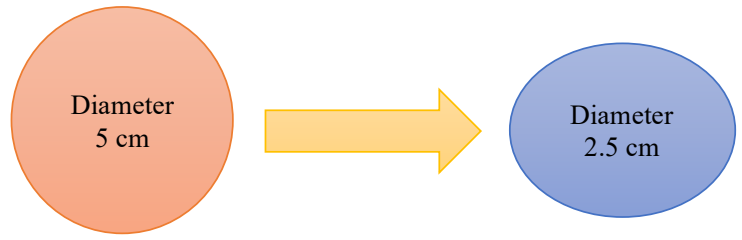

Fig. 4. Size Dimensions of enye chips
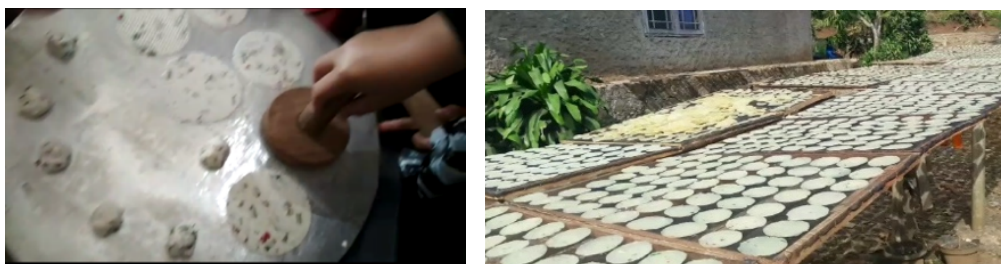

Fig. 5. The Process of Making enye chips with Modification Figure and Drying Process Using Bamboo

As for speeding up drying of enye chips where the pan used originally was to use bamboo, then modified using stainless steel. After baking sheet modification, the drying process which was originally done with bamboo is carried out for 6 hours, after being modified using stainless steel, the drying process is shorter, which is 3 hours. The result of drying is drier and when fried the resulting flavor is crisper. For flavor variants consisting of: (1) Original, (2) Sweet Spicy, (3) Roast Beef / Barbecue

\subsection{Sales training with online media and online shop}

Promotion and sales through social media are done through Instagram and Youtube. For Instagram accounts use a business account named @KeripikEnye Channel. The content in it contains a taste variant of enye chips, a brief profile of enye chips, testimonials from fans of enye chips.

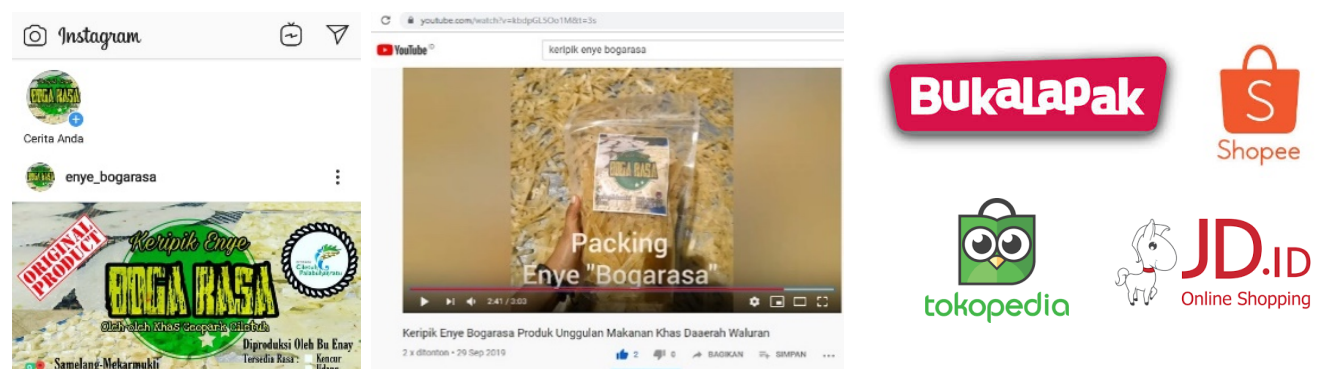

Fig. 6. Display Instagram, YouTube, Facebook and online shop account @bogarasa 
As for the YouTube account created under the name "Enye bogarasa chips", which contains several vlogs of local youtubers testimonials and the profile enye chips.

\subsection{Assistance with Home Industry Licensing Management (P-IRT)}

Assistance is carried out by testing products in the Sukabumi regency labkesda, which consists of testing the nutritional value of food and testing the feasibility of food for consumption. The results of this test are nutritional value and suitable for consumption.

\section{Conclusions and Suggestions}

Innovations in product development need to be done as well as "enye chips" Mekarmukti Waluran, where product innovations are carried out namely branding, packaging and adding flavor variants. After the product innovation, there was an increase in sales and the public was more aware of potential local products in the Ciletuh geopark tourist area. In terms of sales, where prior to this PKM activity was applied, the sales turnover was IDR 6,500,000 per month. But after being given promotion assistance, product development, product legalization, an increase in sales turnover to $\operatorname{Rp~} 8,000,000$ per month. In percentage, there was an increase of $23 \%$ after the partners were involved in this community partnership program activity. This has an impact on improving the community's economy which supports the welfare of the community, especially in Waluran Mekarmukti village.

the suggestion for sustainability is the need for community surveys on taste, shape, and size. so that products vary and increase people's income. this activity must constantly be updating social media content Instagram, Youtube, Bukalapak, Tokopedia etc., so that the "enye chips" village Mekarmukti Waluran can continue to be known by the public.

\section{References}

[1] Badan Pusat Statistik Kabupaten Sukabumi, Kecamatan Waluran Dalam Angka 2018. Koordinator Statistik Kecamatan Waluran (Ed.), Katalog BPS, 2018.

[2] V. W. Hanifah, D. Yulistiani, and S. A. A. Asmarasari, "Optimising the Use of Cassava Pell as Feed for the Empowerment of Enye-Enye Farmers," in Seminar Nasional Teknologi Peternakan dan Veteriner, 2010, pp. 550-556.

[3] S. S. Lebe, M. Mulej, M. P. Bach, J. Zoroja, and M. Merkac-Skok, "Social responsibility in tourism: system archetypes approach," Kybernetes, 2014.

[4] C. Nazzaro, M. Lerro, M. Stanco, and G. Marotta, "Do consumers like food product innovation? An analysis of willingness to pay for innovative food attributes," Br. Food J., 2019.

[5] M. V. S. Fons and J. A. M. Fierro, “y Patiño, MG (2011),“,” Rural Tour. a Sustain. Altern. Appl. Energy, vol. 88, no. 2, pp. 551-557. 